\title{
Estrogen-Induced Sexual Incentive Motivation, Proceptivity and Receptivity Depend on a Functional Estrogen Receptor $\alpha$ in the Ventromedial Nucleus of the Hypothalamus but Not in the Amygdala
}

\author{
Thierry Spiteri $^{\mathrm{a}}$ Sergei Musatov $^{\mathrm{b}, \mathrm{c}}$ Sonoko Ogawa ${ }^{\mathrm{d}}$ Ana Ribeiro $^{\mathrm{b}}$ \\ Donald W. Pfaff ${ }^{\mathrm{b}}$ Anders Ågmo ${ }^{\mathrm{a}}$ \\ ${ }^{a}$ Department of Psychology, University of Troms $\varnothing$, Troms $\varnothing$, Norway; ${ }^{b}$ Laboratory of Neurobiology and Behavior, \\ The Rockefeller University, New York, N.Y., and Neurologix Inc., Fort Lee, N.J., and ' Laboratory of Molecular \\ Neurosurgery, Weill Medical College of Cornell University, New York, N.Y., USA; ${ }^{d}$ Laboratory of Behavioral \\ Neuroendocrinology, University of Tsukuba, Tsukuba, Japan
}

\section{Key Words}

Lordosis $\cdot$ Proceptivity $\cdot$ Sexual motivation $\cdot$ Estrogen receptor $\alpha$ - Ventromedial nucleus of the hypothalamus . Medial posterodorsal amygdala

\begin{abstract}
The display of copulatory behaviors usually requires the presence of a mate and is, therefore, preceded by a search for and approach to a potential partner. The intensity of approach behaviors is determined by a process labeled sexual incentive motivation. Although it is known that female sexual motivation depends on estrogens, their site of action within the brain is unknown. In the present experiment, we obtained data relevant to this issue. An shRNA encoded within an adeno-associated viral (AAV) vector directed against the estrogen receptor $\alpha(E R \alpha)$ gene (or containing a nonsense base sequence as a control treatment) was injected bilaterally into the ventromedial nucleus of the hypothalamus (VMN) or the posterodorsal amygdala (MePDA) of female rats. After an $80 \%$ reduction of the number of $E R \alpha$ in the VMN, sexual incentive motivation was absent after treatment with estradiol and progesterone. Proceptivity and receptivity were also much reduced, while the number of rejections was enhanced. Suppression of the ER $\alpha$ in the
\end{abstract}

MePDA lacked these effects. Likewise, the inactive control $A A V$ vector failed to modify any behavior. Thus, the ER $\alpha$ in the VMN, but not in the MePDA, is important for proceptivity and receptivity as well as for sexual incentive motivation. These results show that $E R \alpha$ in the VMN is crucial for the entire sequence of behavioral events from the processes leading to the establishment of sexual contact until the accomplishment of copulatory behaviors.

Copyright $\odot 2009$ S. Karger AG, Base

\section{Introduction}

Female rodent reproductive behaviors are strictly dependent on ovarian hormones acting within the central nervous system [reviewed in 1]. Studies of mice lacking either a functional estrogen receptor $\alpha(\mathrm{ER} \alpha)$ or estrogen receptor $\beta$ (ER $\beta)$ gene have established that the ER $\alpha$ but not the ER $\beta$ is necessary for the activation of these behaviors by estrogens [2-4]. Likewise, systemic administration of the selective ER $\alpha$ agonist propyl-pyrazole triol to ovariectomized female rats activates receptivity and proceptivity, while the ER $\beta$ agonist diarylpropionitrile is ineffective [5]. Moreover, it is known that a crucial site of action of estrogens is the ventromedial nucleus of the hy-

\section{KARGER}

Fax +4161306 1234

E-Mail karger@karger.ch

www.karger.com (c) 2009 S. Karger AG, Basel

$0028-3835 / 10 / 0912-0142 \$ 26.00 / 0$

Accessible online at:

www.karger.com/nen
Anders Ågmo

Department of Psychology, University of Tromsø

NO-9037 Tromsø (Norway)

Tel. +47 776463 65, Fax +47 77645291

E-Mail andersa@psyk.uit.no 
pothalamus (VMN) [for reviews, see 6, 7]. Additional evidence for this was provided in a recent study where it was shown that infusion of a shRNA encoded within an adeno-associated viral (AAV) vector directed against the $\mathrm{ER} \alpha$ gene into the VMN strongly reduced sexual receptivity and proceptive behaviors in female mice [8].

Displays of receptivity and proceptivity occur when the female is in close physical proximity to the male. In fact, lordosis is a tactile reflex [9] and proceptive behaviors are strongly stimulated by tactile stimuli provided by the male [reviewed in 10,11]. Consequently, few or none of the copulatory behaviors are displayed at a distance from the male. Approach to a male is, then, an event normally preceding displays of copulatory behaviors [12]. There are many observations suggesting that sexual approach behaviors are controlled differently from receptivity and proceptivity. Lesion studies have revealed that receptivity can be abolished without affecting approach to a sexually active male [13] while approach can be affected without reducing receptivity [14]. Some lesions may even enhance receptivity while reducing sexual approach [15]. Thus, the fact that the brain structures and the ER subtype involved in receptivity and proceptivity are quite well known does not mean that this applies to sexual approach behaviors. Furthermore, much of the recent data stem from studies in mice, and it is not evident that the hormone dependence of sexual approach behaviors is identical in rats and mice. In rats, approach to sexually relevant stimuli emitted by an intact male varies during the estrous cycle, with a peak around proestrus $[16,17]$. No such variation occurs in mice [18]. There are even data suggesting that the approach of female mice to stimuli emitted by males is entirely independent of ovarian hormones [19]. These observations indicate that it may be risky to extrapolate the results from mice to rats.

Although the brain areas involved in the control of receptivity and proceptivity as well as the crucial ER are reasonably well known, knowledge concerning sexual approach behaviors is scant. However, data from lesion studies $[20,21]$ suggest that the VMN may be important for these behaviors, in addition to receptivity/proceptivity as mentioned above. However, lesion data do not allow for any conclusion as to the role of ERs, and even less as to the specific ER involved. Another potentially important structure for sexual approach is the amygdala. This structure receives projections both from the main and accessory olfactory systems, and olfactory stimuli are crucial for the activation of approach behaviors [reviewed in 22]. Lesion of the medial posterodorsal amygdala
(MePDA) reduces these behaviors in female rats $[23,24]$. Furthermore, there is a substantial projection from the amygdala to the VMN [25], suggesting that olfactory stimulation reaches the VMN via the amygdala. Thus, among all brain areas potentially involved in sexual approach behaviors, the case for a role of the VMN and the MePDA seems particularly strong.

In the present experiments we suppressed the ER $\alpha$ in the VMN and in the MePDA in ovariectomized female rats with the help of a shRNA directed against the ER $\alpha$ receptor gene [8]. Receptivity, proceptivity and sexual incentive motivation after treatment with estradiol and progesterone were then evaluated. These experiments provide data essential for our understanding of the hormonal control of sexual approach behaviors in addition to extending earlier observations on receptivity and proceptivity in the female mouse to the rat.

\section{Materials and Methods}

Subjects

Male and female Wistar rats were obtained from Charles River WIGA (Sulzfeld, Germany). They were housed 2 per cage under a reversed light-dark cycle (12:12 h, lights off 11:00 h). Food (RM1, Special Diets Services, Witham, Essex, UK) and tap water were always available. Ambient temperature was maintained at $21 \pm$ $1{ }^{\circ} \mathrm{C}$ and relative humidity was $55 \pm 10 \%$. All females (250 g upon arrival to the animal facilities) were ovariectomized and some males (300 g upon arrival) were castrated under isofluorane anesthesia. All experimental procedures employed in the present experiment were approved by the National Animal Research Authority of Norway and were in agreement with the European Union council directive 86/609/EEC.

\section{Stereotaxic Surgery}

About 2 weeks after ovariectomy, some females received intracerebral infusions of either a shRNA encoded within an AAV vector directed against the $\mathrm{ER} \alpha$ gene (ER $\alpha$ shRNA) or with a shRNA containing a nonsense base sequence (AAV control) as well as an independent EGFP (enhanced green fluorescent protein) expression cassette to detect neurons transduced by our viral vector. Hence, EGFP is used as a marker of correct injection localization. The vector AAV control was designed to suppress luciferase expression. The shRNAs employed here have been described in detail elsewhere [8]. Before infusion, the females were fixed in a stereotaxic frame under ketamine/xylazine anesthesia (100 and 10 $\mathrm{mg} / \mathrm{kg}$, respectively). The skull was exposed, and small holes were drilled at the appropriate places after removal of the fascia. Bilateral cannulae (30 gauge) were aimed at the VMN (coordinates were: anteroposterior -2.80 ; mediolateral \pm 0.6 ; dorsoventral $-9.6 ; \mathrm{n}=13$ for ER $\alpha$ shRNA as well as for AAV control), the MePDA (coordinates: anteroposterior -3.14 ; mediolateral \pm 3.6 ; dorsoventral $-8.2 ; \mathrm{n}=13$ for $\mathrm{ER} \alpha$ shRNA as well as for AAV control) or the cerebral cortex dorsal to the VMN (coordinates: anteroposterior -2.80 ; mediolateral \pm 0.6 ; dorsoventral $-2 ; \mathrm{n}=13$ ). 
Coordinates were based on the Paxinos and Watson (1998) atlas. $1 \mu \mathrm{l}$ of PBS solution containing $10^{9}$ packaged genomic particles of one of the viral vectors was injected on each side over a 10-min period using a $10-\mu l$ Hamilton syringe attached to a microinfusion pump. The cannulae were slowly withdrawn 5 min after the end of infusion.

\section{Behavioral Testing}

Tests were performed 3-4 weeks after intracerebral infusion. Experimental females were given estradiol benzoate $(18 \mu \mathrm{g} / \mathrm{kg})$ about $52 \mathrm{~h}$ before behavioral testing was begun. Progesterone ( $1 \mathrm{mg} / \mathrm{rat}$ ) was injected $48 \mathrm{~h}$ after estradiol and $4 \mathrm{~h}$ before the beginning of behavioral tests. Both steroids were purchased from Sigma (St. Louis, Mo., USA), and injected subcutaneously in $1 \mathrm{ml} / \mathrm{kg}$ and $0.2 \mathrm{ml} / \mathrm{rat}$ of peanut oil, respectively. These doses of the ovarian hormones have previously been reported to produce a lordosis quotient (LQ) close to 100 and a sexual incentive motivation of the same magnitude as that observed at proestrus/estrus in intact, cycling rats $[10,17]$.

\section{Test for Unconditioned Sexual Incentive Motivation}

This test has been described in detail elsewhere [10]. Briefly, an oval open field is surrounded by a $45-\mathrm{cm}$-high wall in which there are two diagonally opposed openings $(25 \times 25 \mathrm{~cm})$ at floor level. Outside these openings, incentive animal cages $(25 \times 15 \times$ $25 \mathrm{~cm}$ high) can be fitted. These cages have a double wire mesh front (openings $12 \times 12 \mathrm{~mm}$, distance between the meshes about $10 \mathrm{~mm}$ ) connecting to the observation arena. Within the arena and outside each incentive cage a virtual zone $(30 \times 21 \mathrm{~cm})$ is defined. A video tracking system (Ethovision Pro, Noldus, Wageningen, The Netherlands) determines the experimental subject's position online. An incandescent light bulb provides a white light intensity of about $5 \mathrm{~lx}$ in the arena. Before every experimental session, the arena is cleaned with a $0.1 \%$ solution of glacial acetic acid in water. No cleaning is made between subjects within a session. This is the standard procedure used in the laboratory [26, 27].

The incentives employed were an intact and a castrated male. The same incentive animals were used for all females. At tests, the experimental subject was introduced into the middle of the arena. Immediately thereafter, the experimenter left the room and did not return until just after the end of the 10-min observation period. The subject was then gently removed from the arena, and the following rat was immediately introduced. The position of the incentive animals was semirandomly changed during the experimental session. Spatial location was, therefore, a useless predictor of the endocrine state of the incentives.

The time the experimental subject spent in each incentive zone, the number of visits to the zones, the total distance moved during the test, and the mean velocity while moving were determined. In addition, a preference score (time spent in the intact male zone/time spent in both incentive zones) was calculated.

All females had been familiarized to the apparatus at three sessions of 10 min each performed about 1 week before the experimental test. No ovarian hormones were administered before the familiarization sessions.

Sexually naive females were employed. It has been demonstrated that sexual experience does not modify sexual incentive motivation in female rats $[28,29]$. Furthermore, male odor is an unconditioned incentive for females [30].

\section{Test for Copulatory Behavior}

This test was performed just after the unconditioned sexual incentive motivation test, but in another room. The experimental female was introduced into a rectangular observation cage $(40 \times$ $60 \times 40 \mathrm{~cm}$ high) with a Plexiglas front where a sexually experienced male was waiting. The test lasted until the female had received 10 mounts with pelvic thrusting. The presence or absence of lordosis in response to each mount was recorded. Receptivity was quantified as the LQ (the number of lordosis displayed divided by the number of mounts received multiplied by 100). Proceptive behaviors (hop-darting and ear-wiggling) as well as rejections (kicking, boxing, fleeing) were also recorded.

\section{Immunocytochemistry}

The day following the behavioral tests the subjects were euthanized with carbon dioxide. Females were perfused with PBS followed by $4 \%$ paraformaldehyde. The brain was removed and postfixed overnight at $4{ }^{\circ} \mathrm{C}$ in $4 \%$ paraformaldehyde. It was then rinsed with PBS and cryoprotected in $30 \%$ sucrose in PBS. After $24 \mathrm{~h}$ in the sucrose solution, the brain was frozen in isopentane cooled on dry ice, and then transferred to a $-80^{\circ} \mathrm{C}$ freezer for storage until processing.

Brains were frozen-sectioned at $50 \mu \mathrm{m}$ with a microtome. According to injection localization, alternate sections containing the VMN or the MePDA were collected and processed according to a conventional free-floating protocol. Antibodies against the ER $\alpha$ (polyclonal, 1:25,000; Upstate, Lake Placid, N.Y., USA) and EGFP (GFP, Abcam, Cambridge, Mass., USA) were used in combination with secondary antibodies (biotinylated rabbit) and avidin-biotin peroxidase complex (ABC Elite Kit from Jackson Immunoresearch, West Grove, Pa., USA) to identify cells containing $\mathrm{ER} \alpha$ and transduced cells, respectively. After antibody reactions, sections were stained with diaminobenzidine. This staining gave a brown coloration to EGFP. Hence, neurons transduced with our virus were labeled by brown cytoplasmic staining. In contrast, this staining colored the ER $\alpha$ in purple. Thus, brown-stained cells indicated injection localization while purple-stained cell showed $\mathrm{ER} \alpha$ expression.

For comparisons between experimental and control groups, the number of ER $\alpha$-stained cells in the VMN and the MePDA was determined. For this, photographs of each nucleus were taken by a combination of microscope (Nikon Eclipse E400) and camera (Nikon CoolPix 990). Then, pictures were transferred to a computer and opened by Photoshop software. By a virtual pen, zones were drawn over the VMN and the MePDA and the stained cells within were counted. The number of ER $\alpha$ was divided by the surface of each nucleus in order to obtain a density (number of ER $\alpha$ / $\mathrm{mm}^{2}$ ). In order to determine the spread of ER $\alpha$ knockdown, ER $\alpha$ stained cells were also counted in structures adjacent to the injection sites, the arcuate nucleus for the VMN and the posteroventral amygdala for the MePDA.

\section{Design}

Five groups of 13 rats each were used: (1) ER $\alpha$ shRNA infused into the MePDA; (2) AAV control infused into the MePDA; (3) ER $\alpha$ shRNA infused into the VMN; (4) AAV control infused into the VMN, and (5) $\mathrm{ER} \alpha$ shRNA infused into the cerebral cortex. 
Data Analysis

Only rats with successful and effective bilateral virus infusion at the intended site (the VMN or the MePDA) were included in the analyses. In these animals, the number of ER $\alpha$-immunoreactive cells in the groups treated with ER $\alpha$ shRNA in the VMN and in the cerebral cortex and those treated with AAV control in the VMN was evaluated with one-factor ANOVA. A t test was performed for the groups infused with ER $\alpha$ shRNA and AAV control in the MePDA.

Behavioral data from the three groups infused with $\mathrm{ER} \alpha$ shRNA and AAV control into the VMN as well as the group infused with ER $\alpha$ shRNA into the cerebral cortex above the VMN were analyzed separately from the groups infused with ER $\alpha$ shRNA and AAV control in the MePDA. In the first case, sexual incentive motivation data were analyzed with one-factor ANOVA (preference score, distance moved, velocity of movement, time moving) or with two-factor ANOVA for repeated measures on one factor (time spent in the incentive zones). The between-groups factor was treatment $(\mathrm{ER} \alpha$ shRNA in the VMN, ER $\alpha$ shRNA in the cerebral cortex, AAV control in the VMN), while the withingroups factor was incentive (intact male vs. castrated male). In case of non-homogenous error variances, as determined by Levene's test, data were subjected to a logarithmic transformation. Following significant ANOVA, Tukey's HSD test was employed for determining group differences. In case of significant interaction, tests for simple main effects within treatments as well as within incentives were performed. The preference score was also compared to no preference (i.e., a score of 0.5 ) with a t test in each group. Data from the test for copulatory behavior were analyzed with Kruskal-Wallis non-parametric ANOVA followed by Nemenyi's test [31] in case of significance.

Sexual incentive motivation data from the MePDA groups were analyzed with t test or with two-factor ANOVAs when appropriate. Copulatory behaviors were evaluated with the MannWhitney U test. Relationships between parameters of copulatory behavior and sexual incentive motivation were evaluated with Spearman's rank correlation. A two-tailed significance level of 0.05 was used in all analyses.

\section{Results}

\section{Histology}

Of the 13 animals infused with the shRNA directed against the $\mathrm{ER} \alpha$ gene into the $\mathrm{VMN}, 4$ had cannulae tips outside this nucleus. Thus, 9 females remained in the ER $\alpha$ shRNA VMN group. The 4 animals with misplaced infusions were included in the cortex group, which thus ended up with an $n=17$. There are 13 animals in each groups infused by AAV control into the VMN and the MePDA as well as the group infused by ER $\alpha$ shRNA into the MePDA.

As can be seen in figure 1a, the number of ER $\alpha$ was significantly reduced in animals infused with ER $\alpha$ shRNA into the VMN compared to animals infused into the cortex and those infused with AAV control,
$\mathrm{F}(2,38)=37.74, \mathrm{p}<0.001$. The Tukey HSD test revealed that the group infused with ER $\alpha$ shRNA into the VMN had a lower number of $\mathrm{ER} \alpha$ than the groups infused with AAV control into the VMN as well as the group infused with $\mathrm{ER} \alpha$ shRNA into the cortex. In the same way, ER $\alpha$ were significantly fewer in animals infused with ER $\alpha$ shRNA than those infused with AAV control into the MePDA, $\mathrm{t}(24)=9.479, \mathrm{p}<0.001$. Indeed, there was a reduction of $\mathrm{ER} \alpha$ expression of $80 \%$ in the $\mathrm{VMN}$, and of $81 \%$ in the MePDA. It can also be seen that the suppression of ER $\alpha$ is site-specific. The ER $\alpha$ staining in the adjacent arcuate nucleus was unaffected by infusion of ER $\alpha$ shRNA or AAV control into the VMN as well as by ER $\alpha$ shRNA infusion into the cortex, $\mathrm{F}(2,38)=0.957$ (fig. 1b, 2). Likewise, the group infused with ER $\alpha$ shRNA into the MePDA presented low $\mathrm{ER} \alpha$ staining there but not in the medial posteroventral amygdala, $\mathrm{t}(24)=1.873$, not significant (ns) (fig. $1 \mathrm{~b}$ ).

\section{Behavioral Effects of ER $\alpha$ Knockdown in the VMN}

Sexual Incentive Motivation. No group differences in velocity, distance moved or time moving were found either between the VMN groups, $\mathrm{F}(2,38)=1.396$, ns, $\mathrm{F}(2,38)=0.926$, ns, and $\mathrm{F}(2,38)=2.575$, ns, respectively, or between the MePDA groups, $\mathrm{t}(24)=0.638$, ns, $\mathrm{t}(24)=$ 0.610 , ns, and $\mathrm{t}(24)=1.2$, ns, respectively. Hence, these parameters are not further mentioned.

There was a significant main effect of treatment on the preference score, $\mathrm{F}(2,38)=9.521, \mathrm{p}<0.001$. The Tukey HSD test revealed that the group infused with AAV control into the VMN as well as the group infused with ER $\alpha$ shRNA into the cortex had a higher preference score than the group infused with ER $\alpha$ shRNA into the VMN. The preference score in the latter group was not different from 0.5 (no preference), $\mathrm{t}(8)=0.773$, ns, while the animals in the other two groups preferred the intact over the castrated male, $t(12)=6.494, p<0.001$ for the group infused with AAV control into the VMN, and $t(16)=7.302, p<0.001$ for the group infused with ER $\alpha$ shRNA into the cortex.

Concerning the time spent in the incentive zones, there was a significant main effect on incentive, $\mathrm{F}(1,36)=$ 47.306, $\mathrm{p}<0.001$. The interaction treatment $\times$ incentive was also significant, $\mathrm{F}(2,36)=8.509, \mathrm{p}<0.001$. There was no effect of treatment, $F(2,36)=1.956$, ns. Tests for simple main effects of incentive within treatment showed that the subjects treated with ER $\alpha$ shRNA into the VMN spent as much time in the castrated male's incentive zone as they did in the intact male's incentive zone, $F(1,36)=$ 0.35 , ns. At difference, animals infused with AAV control into the VMN or with ER $\alpha$ shRNA into the cortex spent more time in the intact male's incentive zone, $\mathrm{F}(1,36)=$ 


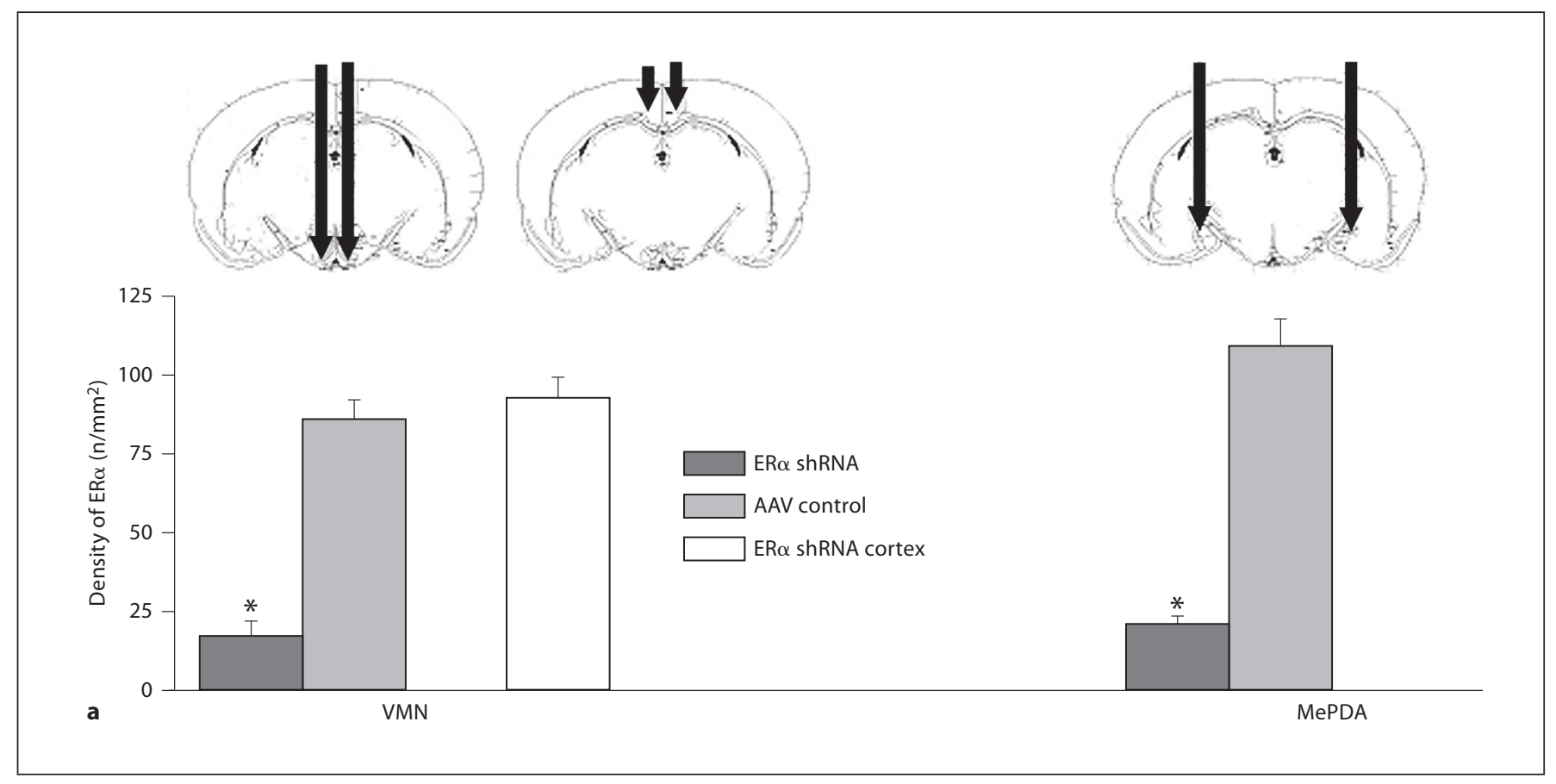

Fig. 1. a Mean \pm SEM number of ER $\alpha$ in the VMN and MePDA after bilateral infusion of an AAV-associated shRNA directed against the $\mathrm{ER} \alpha$ gene ( $\mathrm{ER} \alpha$ shRNA in the figure; $\mathrm{VMN}, \mathrm{n}=9$; MePDA, $n=13$; cerebral cortex, $n=9$ ) or a control shRNA (AAV control in the figure; VMN, $\mathrm{n}=9$; MePDA, $\mathrm{n}=13$ ) into these structures. The sites of injection are illustrated by the bars. b Number of ER $\alpha$ in structures adjacent to the infusion sites, the medial arcuate nucleus (ArcM) for the VMN and the posteroventral amygdala (MePV) for the MePDA. In addition, the number of $\mathrm{ER} \alpha$ in the VMN of animals given an infusion into the cerebral cortex above the VMN is shown. ER $\alpha$ shRNA, the group of females injected by shRNA against the $\mathrm{ER} \alpha$ gene either in the VMN or in the MePDA; AAV control, the group of females injected by inactive shRNA either in the VMN or in the MePDA; ER $\alpha$ shRNA cortex, the group of females injected by shRNA against the ER $\alpha$ gene in the cortex. ${ }^{*} \mathrm{p}<0.05$ compared to ER $\alpha$ shRNA.

22.78, $\mathrm{p}<0.001$ and $\mathrm{F}(1,36)=61.18, \mathrm{p}<0.001$, respectively. When the effect of treatment within incentive was analyzed, it was found that there was no treatment effect on the time spent in the castrated male's incentive zone, $\mathrm{F}(2,36)=4.36$, ns, while the groups differed with regard

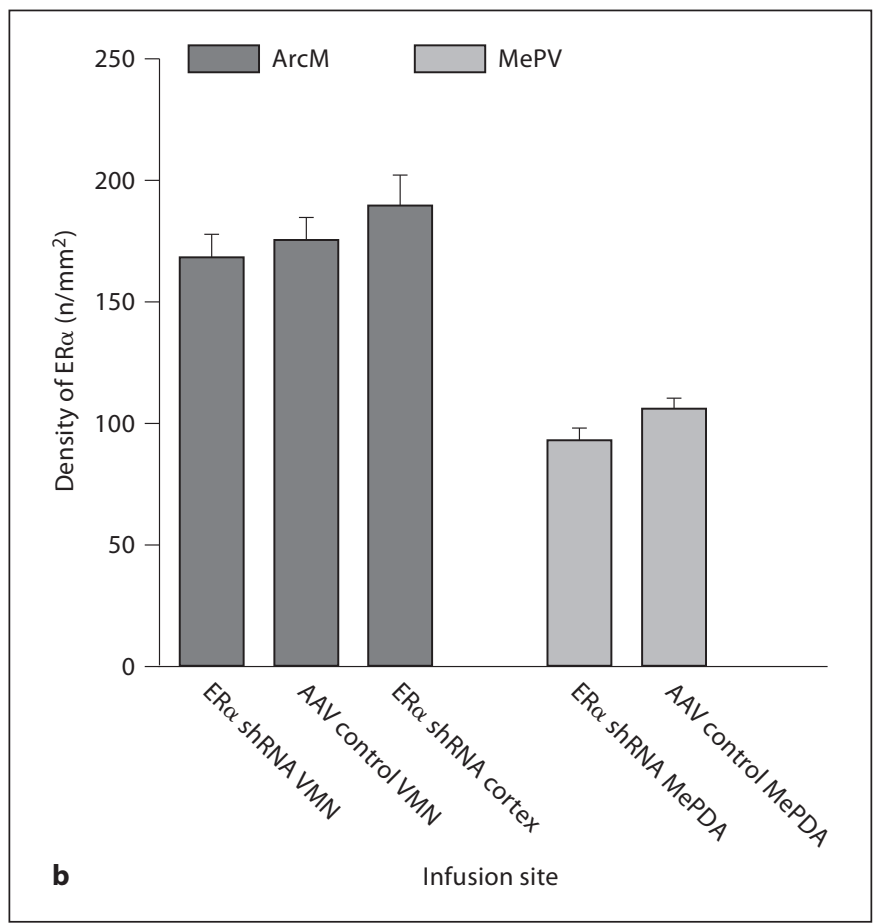

to the time spent in the intact male's incentive zone, $\mathrm{F}(2,36)=7.45, \mathrm{p}<0.01$. Tukey's HSD test showed that the group infused with ER $\alpha$ shRNA into the VMN spent less time in this zone than the group infused with $\mathrm{ER} \alpha$ shRNA into the cortex. 
ER $\alpha$ shRNA VMN
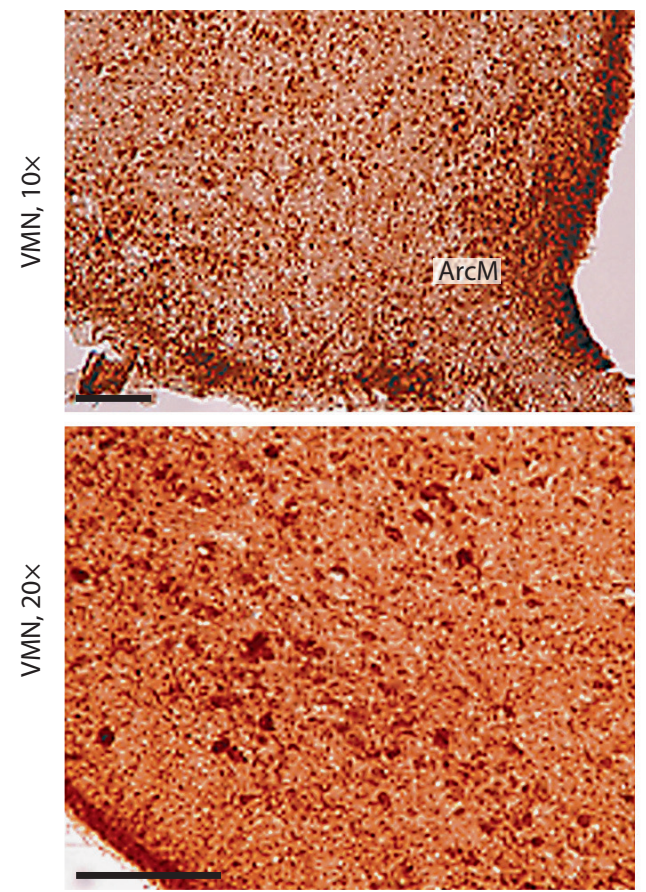

Treatment

AAV control VMN
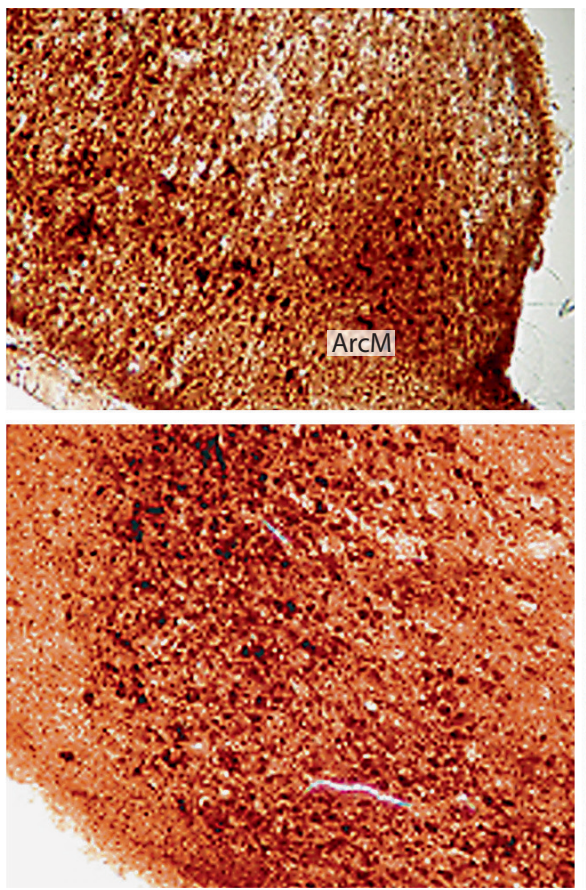

$E R \alpha$ shRNA cortex
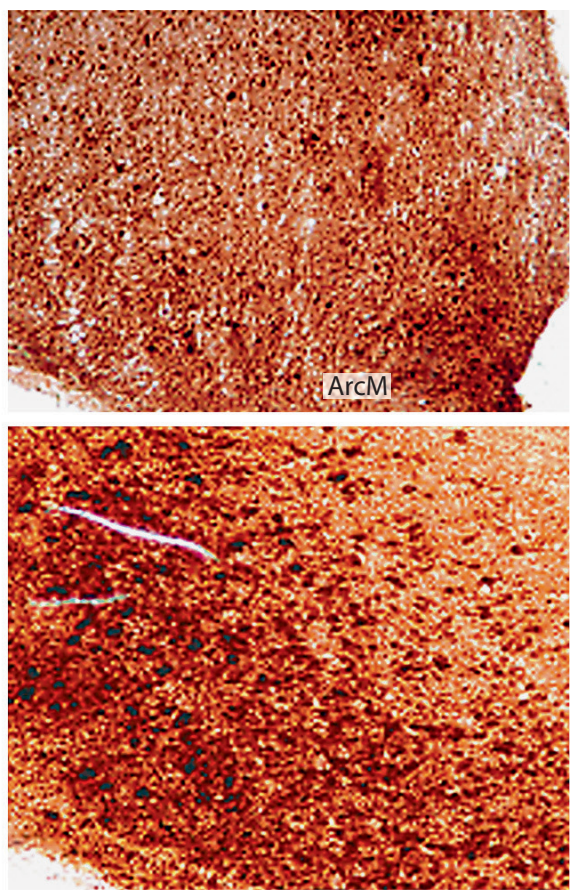
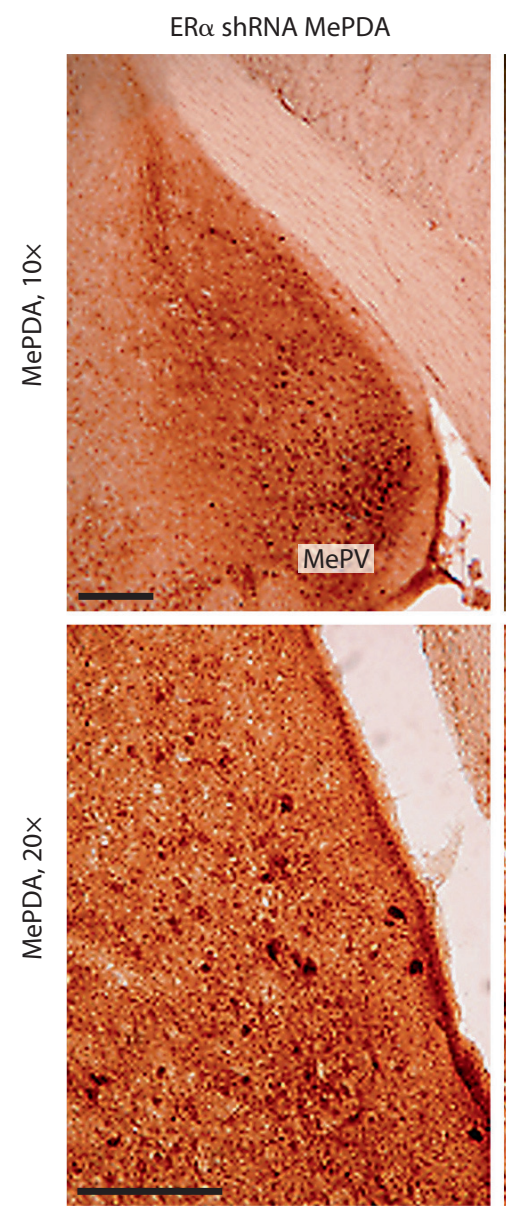

AAV control MePDA
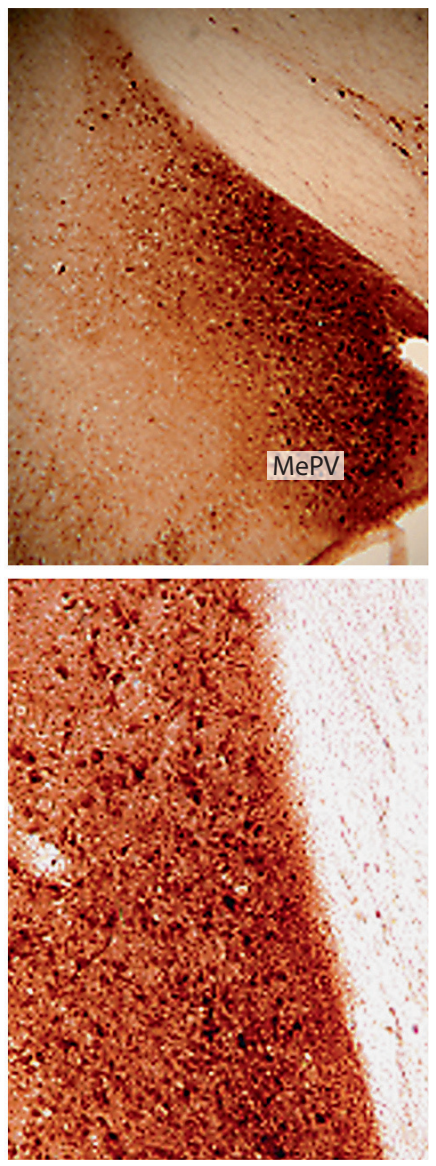

Fig. 2. Immunocytochemical staining of brain slices in the $\mathrm{VMN}$ and the MePDA. Only slices with the greatest ER $\alpha$ staining have been chosen. Scale bar is $200 \mu \mathrm{m}$. ArcM = Arcuate nucleus; $\mathrm{MePV}=$ medial posteroventral amygdala. Notice a reduction of ER $\alpha$ staining in the VMN and MePDA but not in the ArcM and MePV in animals infused with ER $\alpha$ shRNA compared to animals infused into the cortex and those infused with AAV control.

Sexual Behavior Effects of ER $\alpha$ in the 

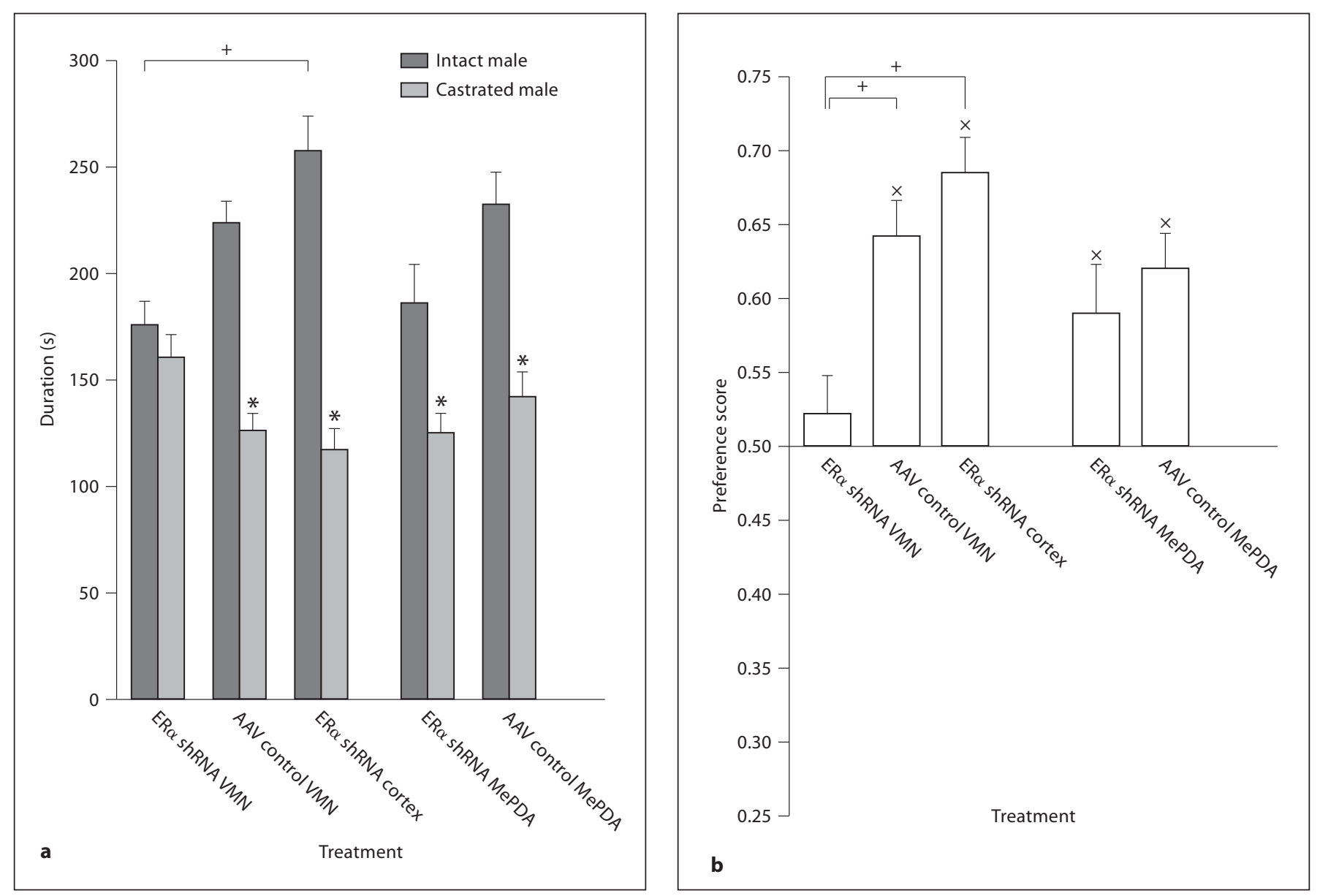

Fig. 3. Mean \pm SEM of parameters of sexual incentive motivation in female rats with a reduced number of ER $\alpha$ in the VMN or MePDA and the corresponding controls. a Time (s) spent in the intact and castrated male incentive zones, respectively. b Preference score. Subjects treated with ER $\alpha$ shRNA in the VMN do not approach the sexual incentive more than the social incentive, while the same treatment in the MePDA fails to reduce sexual incentive motivation. ${ }^{*}$ Different from the time spent in the intact male zone, $\mathrm{p}<0.05 .{ }^{\times}$Different from no preference (a score of 0.5 ), $\mathrm{p}<0.05$. Lines indicate significant differences between groups: ${ }^{+} \mathrm{p}<0.05$. For further details, see legend to figure 1 .

Regarding the total time spent close to both incentive zones, females infused with ER $\alpha$ shRNA into the VMN spent $335 \pm 12 \mathrm{~s}$ in the incentive zones, while females infused with AAV control into the VMN or with ER $\alpha$ shRNA into the cortex spent $349 \pm 10$ and $374 \pm 15 \mathrm{~s}$, respectively. These differences are not significant, $\mathrm{F}(2,36)=1.956$, ns. Data are illustrated in figure $3 \mathrm{a}$ and $b$.

Copulatory Behavior. The LQ differed between the three VMN groups, $\mathrm{H}=17.985, \mathrm{p}<0.001$. The Nemenyi's test showed that the group infused with ER $\alpha$ shRNA had a lower LQ than the other groups (fig. 4a). Similar effects were obtained with regard to proceptive behaviors, $\mathrm{H}=$
19.180, $\mathrm{p}<0.001$ (fig. 4b). The number of rejections showed an inverse pattern, with a large number in the group infused with ER $\alpha$ shRNA and a low number in the other groups, $\mathrm{H}=19.180, \mathrm{p}<0.01$ (fig. $4 \mathrm{c}$ ).

\section{Behavioral Effects of ER $\alpha$ Knockdown in the MePDA}

\section{Sexual Incentive Motivation}

The shRNA had no effect on preference score (all comparisons between the ER $\alpha$ shRNA and AAV control groups had $\mathrm{p}>0.065)$. Both groups preferred the intact over the castrated male, and spent more time with the intact male (all $\mathrm{p}<0.01)$. 


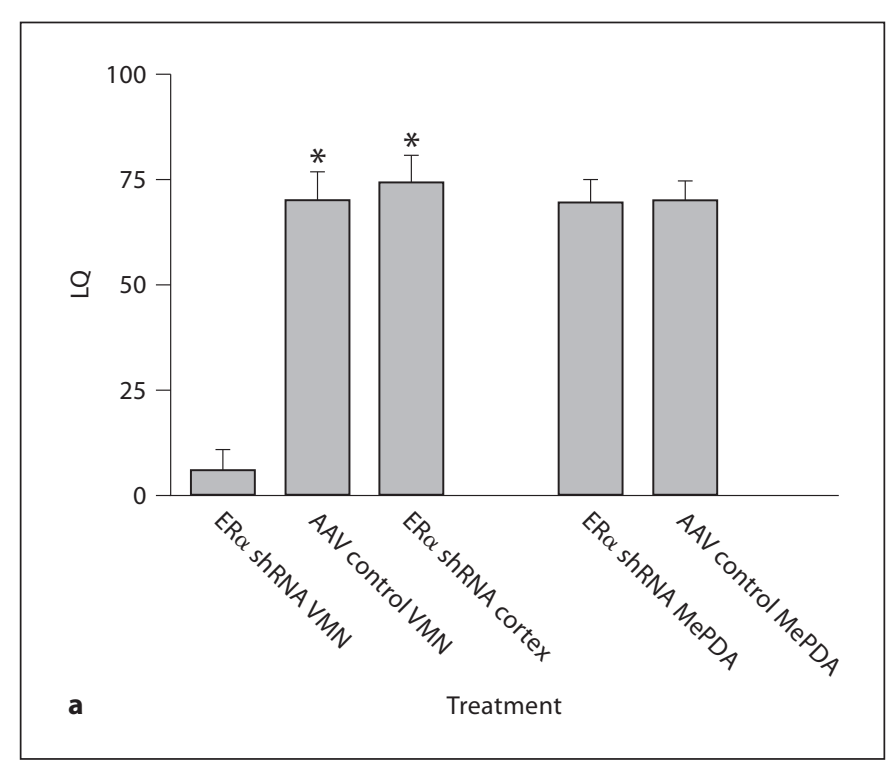

Fig. 4. a Lordosis quotient (LQ), b proceptive behaviors and $\mathbf{c}$ rejections in female rats with a reduced number of ER $\alpha$ in the VMN or MePDA and the corresponding controls. After a substantial reduction of $\mathrm{ER} \alpha$ in the $\mathrm{VMN}$, proceptivity and receptivity (lordosis) were reduced while rejections were enhanced. No effects were observed after a similar reduction of the ER $\alpha$ in the MePDA. Data are mean \pm SEM. * Different from ER $\alpha$ shRNA, $\mathrm{p}<0.05$. For further details, see legend to figure 1.

Females infused with ER $\alpha$ shRNA into the MePDA spent $310 \pm 18 \mathrm{~s}$ in both incentive zones, while females infused with AAV control into the MePDA spent $373 \pm$ $16 \mathrm{~s}$. This difference is significant, $\mathrm{t}(24)=2.533, \mathrm{p}<0.05$. However, considering the incentive zones separately, females infused with ER $\alpha$ shRNA into the MePDA did not spend less time close to the castrate male than those infused with AAV control into the MePDA did, $t(24)=$ $1.143, \mathrm{~ns}$. This is also the case for the time spent close to the intact male, $\mathrm{t}(24)=1.291$, ns. Data are summarized in figure $3 a$ and $b$.

Sexual Behavior Effects of $E R \alpha$ in the VMN
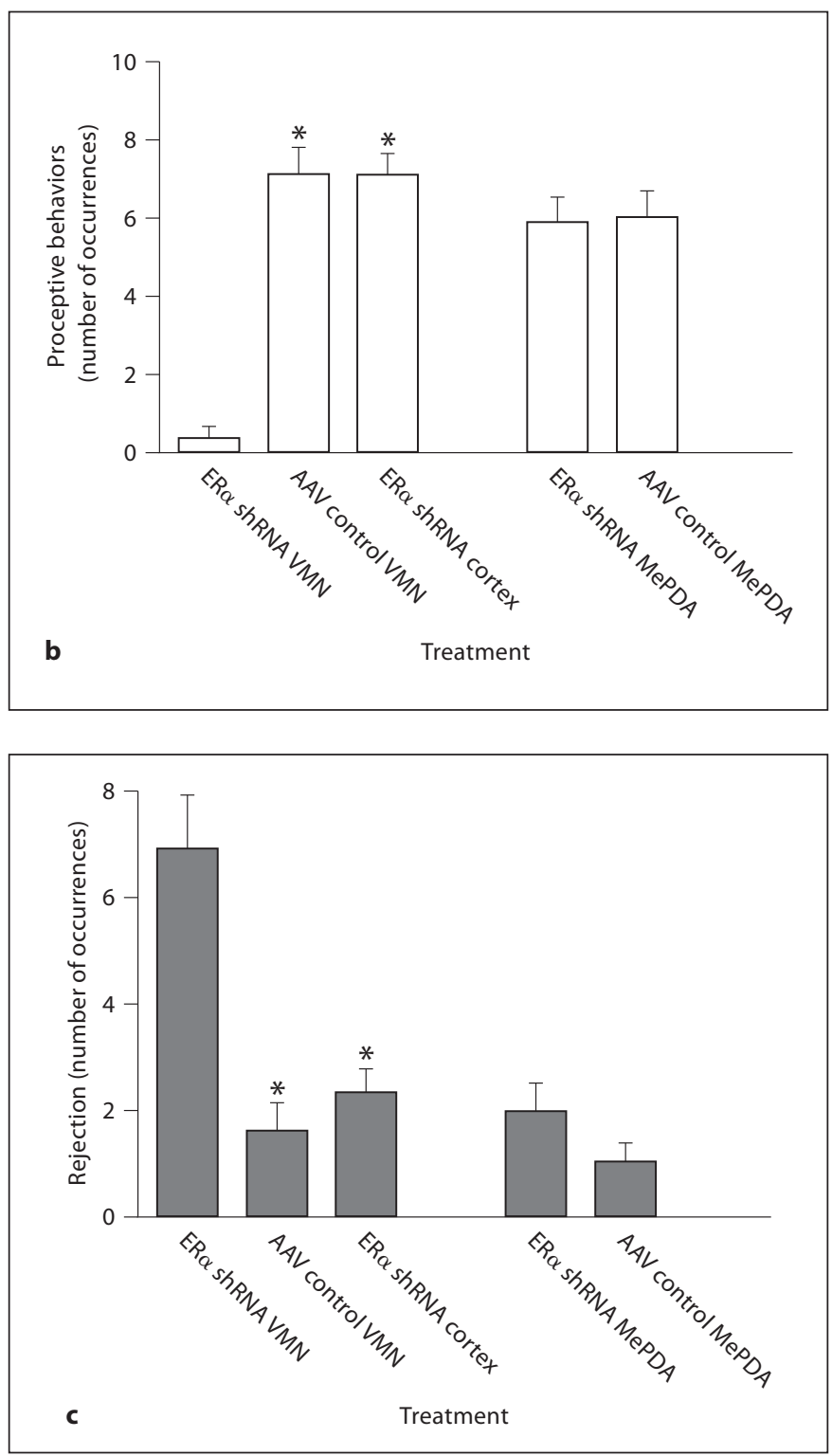

\section{Copulatory Behavior}

Although females in the group infused with ER $\alpha$ shRNA into the MePDA had a substantial reduction of the number of ER $\alpha$ in this structure, neither LQ nor proceptive behaviors or rejections were affected (all $\mathrm{p}>$ 0.545; fig. 4a-c).

\section{Relationship between Effects of ER $\alpha$ Knockdown on Sexual Incentive Motivation and on Copulatory \\ Behavior}

As expected, there was a strong parallelism between results from the sexual incentive motivation test and 
those from the copulatory behavior test. Female rats displaying receptivity and proceptivity showed also normal sexual incentive motivation. There were positive correlations between LQ, $\rho=0.400, p<0.05$, as well as between proceptive behaviors, $\rho=0.428, \mathrm{p}<0.01$, and preference score. Likewise, the reduction of lordosis and proceptive behaviors due to silencing of ER $\alpha$ expression in the VMN was accompanied by rejection and absence of sexual incentive motivation. Indeed, rejection was negatively correlated with preference score, $\rho=-0.407, \mathrm{p}<0.05$, $\mathrm{LQ}, \rho=-0.728, \mathrm{p}<0.01$, and proceptive behaviors, $\rho=$ $-0.705, p<0.01$. These results reinforce the notion that sexual incentive motivation and copulatory behavior are equally determined by the ER $\alpha$.

\section{Discussion}

\section{Specificity of the ER $\alpha$ Knockdown}

The RNAi employed in the experiments reported herein turned out to be a most efficient tool for drastically reducing the amount of immunoreactive ER $\alpha$ in a small area around the infusion sites while leaving this receptor unaffected in adjacent structures. It is also noteworthy that an infusion into the cerebral cortex, placed exactly above the VMN, failed to affect $\mathrm{ER} \alpha$ expression in the $\mathrm{VMN}$ or the MePDA. It may be important to mention that the shRNA employed here does not affect the $\mathrm{ER} \beta$ [8]. It is, consequently, not unreasonable to propose that all effects observed after infusion into the VMN or the MePDA are a result of a reduced number of ER $\alpha$ in these specific structures.

\section{Effects of ER $\alpha$ Knockdown on Sexual Motivation}

An $80 \%$ reduction of the ER $\alpha$ in the VMN abolished sexual incentive motivation, expressed as approach to a potential mate, in the female rat. A similar effect has been reported after partial or complete lesion of the VMN [20, 21]. Present results show that estrogen actions on the ER $\alpha$ within the VMN are necessary for the activation of sexual approach behaviors in response to stimuli emitted by an intact male. An important issue is whether such actions also are sufficient for the display of sexual approach. Present data do not allow for any conclusion about this. It could also be maintained that the reduction of $E R \alpha$ in either brain structure disrupted attraction to conspecific males regardless of their reproductive status. ER $\alpha$ knockdown in the VMN did not reduce the total time spent in the incentive zones, making such a proposal unlikely. However, the reduction of the ER $\alpha$ in the MePDA pro- vided less clear results. While the preference for the intact male was not reduced, the total time spent in the incentive zones was. Since both the intact and castrated males have social incentive properties, the intact male having sexual incentive properties in addition, this could indicate that a reduction of ER $\alpha$ in the MePDA reduces social motivation. This proposal is somewhat weakened by the fact that neither the time spent in the intact male incentive zone nor that spent in the castrated male's incentive zone was reduced when analyzed separately.

Another issue is whether the shRNA directed against the ER $\alpha$ impaired olfactory discrimination after infusion into the VMN. If the females could not distinguish between olfactory cues emitted by the intact male from those emitted by the castrated male, they could obviously not show any preference for the intact male. There are, indeed, some data suggesting that estrogens enhance odor detection capacity in mice [32]. However, differences between untreated ovariectomized and estrogen-treated females become evident only after a substantial dilution of male urine. In rats, ovariectomy improves detection of volatile odors $[33,34]$. These data suggest that absence of estrogens does not impede the females from distinguishing an intact from a castrated male. Consequently, it is unlikely that the absence of sexual incentive motivation in the females with a reduced number of $E R \alpha$ in the VMN can be attributed to olfactory deficits.

Sexual approach behaviors are activated by olfactory stimuli, since bedding soiled by an intact male or urine from such males are approached more than bedding soiled by a castrated male or another female or urine from these animals [35-37] even if direct physical contact with the olfactory stimulus is impossible [36, 38-40]. Olfactory stimuli are, then, sufficient for inducing sexual approach in female rats since they do so in the absence of other kinds of stimuli. They are also necessary, since section of the olfactory nerves (without causing damage to the olfactory bulbs) eliminates approach behaviors [23]. The chemical stimulus passes from the olfactory epithelium to the main olfactory bulb and from there to the amygdala. Intrinsic connections in the amygdala allow the stimulus to access the MePDA [41]. Finally, the MePDA projects to the VMN and preoptic area, mainly through the stria terminalis [42]. ERs have been reported to be present in olfactory epithelial tissue [43], primary olfactory neurons [44], main and accessory olfactory bulbs and in the amygdala [45-47]. It is not impossible that estrogen actions on ER $\alpha$ in several or some of these structures, in addition to actions within the VMN, are required for sexual approach behaviors. However, an $80 \%$ 
reduction of the number of $\mathrm{ER} \alpha$ in the MePDA did not affect the intensity of approach behaviors suggesting that any possible estrogen actions in the MePDA are not necessary. If the ER $\alpha$ affects sensory systems in a way significant for approach, it must be either in the olfactory bulbs or in the nasal epithelium.

Efferent projections from the VMN to the midbrain follow medial and lateral routes terminating mainly in the dorsal and lateral part of the periaqueductal gray [48]. Bilateral transection of lateral efferent fibers from VMN to midbrain disrupts sexual partner preference in female rats [49]. This suggests that these axons from the VMN to the periaqueducal gray mediate estrogen action involved in sexual approach behaviors. Likewise, present results suggest that the crucial site of action for estradiol in controlling the intensity of sexual approach behaviors, frequently considered an expression of sexual incentive motivation, is localized to the VMN. Whether downstream ER-containing structures have any modulatory role in the control of sexual incentive motivation or not needs to be analyzed in future studies.

\section{Effects of ER $\alpha$ Knockdown on Copulatory Behaviors}

A reduction of the number of ER $\alpha$ in the VMN also reduced the display of lordosis and proceptive behaviors. To the contrary, rejections are much enhanced in females with few ER $\alpha$ in that structure. These results coincide with data from the mouse [8]. Similar observations have earlier been made after different kinds of lesion of the VMN [50-52] or following implants of ER antagonists $[53,54]$. Since the implantation of minute amounts of estradiol into the VMN activates complete female copulatory behavior $[55,56]$, it appears that the $\mathrm{VMN}$ is not only necessary but also sufficient for this behavior. Independently of this, it is conceivable that estrogen actions outside the VMN might modulate some aspects of female copulatory behavior.

One of the main efferent projections of the VMN is to the periaqueductal central gray [57], and lesion of this structure has been found to strongly reduce lordosis [e.g. $58,59]$. However, implants of estradiol within this structure are not able to activate lordosis unless the VMN is simultaneously exposed to estrogens [60]. Nevertheless, estradiol affects neuronal firing within this structure [61] and could, consequently, modify the display of lordosis. The periaqueductal central gray also receives important projections from the lateral septum and the preoptic area [62], and is in an excellent position for integrating lordosis facilitating input from the VMN and inhibitory inputs from the preoptic area and lateral septum. Whether such an integration is modulated by the $\mathrm{ER} \alpha$ or not remains unknown.

Destruction of the olfactory epithelium does not modify the expression of lordosis [63]. To the contrary, lesions of the olfactory bulb have consistently been found to enhance lordosis in female rats [63-66], facilitate the display of proceptive behaviors [67], and probably reduce fear signals. ERs in the olfactory bulb could, in principle, be involved in these effects. Results from the present experiment do not allow for any conclusion as to the role of the $\mathrm{ER} \alpha$ in the olfactory primary projection areas.

Lesion of the MePDA has been reported to enhance lordosis intensity and proceptive behaviors $[68,69]$ while leaving pacing behavior unaffected [70]. These data suggest that neurons in the MePDA may exert some inhibitory action on lordosis and proceptivity. The results of the present experiment suggest that any such effect is independent of the $\mathrm{ER} \alpha$, since animals with a much reduced number of these receptors in the MePDA did not have proceptive behaviors or lordosis different from controls.

\section{Possible Role of Progesterone Receptors}

One of the main cellular effects of estrogens is to enhance the number of progesterone receptors. There are data suggesting that this effect depends on the ER $\alpha$ [71]. Consequently, it is possible that the number of available progesterone receptors was much reduced in the VMN and MePDA, respectively, after administration of the shRNA directed against the ER $\alpha$. Since progesterone receptors were not counted, the magnitude of this reduction is unknown. Nevertheless, a lack of progesterone action could explain the absence of sexual incentive motivation in the group with reduced number of $E R \alpha$ in the VMN. In fact, ovariectomized females treated with estradiol alone fail to show any preference for an intact male [16]. Likewise, receptivity is enhanced by progesterone in females treated with low doses of estradiol [72]. Furthermore, proceptivity is progesterone-dependent unless very high doses of estradiol are administered [73]. In principle, all the behavioral effects found in the present experiments could be attributed to reduced progesterone action. However, in the ER $\alpha$ knockout mouse, estradiol preserves the capacity to enhance progesterone receptor immunoreactivity in the VMN, albeit to a lower extent than in the wild type $[74,75]$. Despite the presence of estrogen-induced progesterone receptors, these mice show only marginal levels of female sexual behaviors [76]. This fact suggests that additional factors, besides progesterone receptor availability, are involved in the reduction of sex behaviors in these mice. Furthermore, even if a decrease 
in progesterone receptor induction were involved in the effects found in the present experiment, the fact that sexual incentive motivation and copulatory behaviors are strongly reduced in females with a reduced number of $\mathrm{ER} \alpha$ in the VMN is not altered.

\section{Conclusion}

The results obtained in the experiment reported here demonstrate that the ER $\alpha$ in the VMN is crucial for the entire sequence of behavioral events from the processes leading to the establishment of sexual contact until the accomplishment of copulatory behaviors. This constitutes strong evidence for the assertion that the ER $\alpha$ in the VMN is necessary for all aspects of female rat sexual behavior. We even speculate that estrogen action in VMN may be sufficient for these behaviors. It seems, then, that the VMN somehow determines if sensory input, be it tactile or olfactory, should be relayed to motor systems or not. In the presence of an activated ER $\alpha$, the likelihood for connecting the sensory and motor systems is high, while it is low or entirely absent when the ER $\alpha$ is not ac- tivated. The notion of the VMN as a central actor in the control of female sexual behaviors was eloquently elaborated long ago $[6,7]$, but here we offer additional support and provide data as to the ER involved. Present results also show that the ER $\alpha$ in the MePDA does not influence female sexual behaviors to any significant degree. Further studies selectively manipulating the $\mathrm{ER} \alpha$ in several parts of the olfactory pathway, the preoptic area and the septum as well as the periaqueductal gray and other projection areas of the VMN are necessary before we can achieve a complete picture of estrogen activation of female sexual behaviors. Such studies are perfectly feasible, and it is to be hoped that we soon will have a detailed understanding of the neural circuits, and the actions of estrogens thereupon, responsible for all aspects of female sexual behavior.

\section{Acknowledgements}

Expert technical assistance was provided by Ragnhild Osnes, Stig Rune Olsen, Carina Sørensen and Nina Løvhaug. Financial support was received from the University of Tromsø (to T.S. and A.A.) and from grants MH 38273 and HD 05751 to D.W.P.

\section{References}

1 Blaustein JD, Erskine MS: Feminine sexual behavior: cellular integration of hormonal and afferent information in the rodent brain; in Pfaff DW, Arnold AP, Etgen AM, Fahrbach SE, Rubin RT (eds): Hormones, Brain and Behavior. New York, Academic Press, 2002, vol 1, pp 139-214.

-2 Ogawa S, Eng V, Taylor J, Lubahn DB, Korach KS, Pfaff DW: Roles of estrogen receptor- $\alpha$ gene expression in reproduction-related behaviors in female mice. Endocrinology 1998;139:5070-5081.

-3 Rissman EF, Early AH, Taylor JA, Korach KS, Lubahn DB: Estrogen receptors are essential for female sexual receptivity. Endocrinology 1997; 138:507-510.

-4 Ogawa S, Chan J, Gustafsson JÅ, Korach KS, Pfaff DW: Survival of reproductive behaviors in estrogen receptor $\beta$ gene-deficient ( $\beta E R K O)$ male and female mice. Proc Natl Acad Sci USA 1999;96:12887-12892.

5 Mazzucco CA, Walker HA, Pawluski JL, Lieblich SE, Galea LAM: ER $\alpha$, but not ER $\beta$, mediates the expression of sexual behavior in the female rat. Behav Brain Res 2008; 191:111-117.

6 Pfaff DW: Drive. Neurobiological and Molecular Mechanisms of Sexual Motivation. Cambridge, MIT Press, 1999.
7 Pfaff DW: Estrogens and Brain Function: Neural Analysis of a Hormone-Controlled Mammalian Reproductive Behavior. New York, Springer, 1980.

$>8$ Musatov S, Chen W, Pfaff DW, Kaplitt MG, Ogawa S: RNAi-mediated silencing of estrogen receptor $\alpha$ in the ventromedial nucleus of the hypothalamus abolishes female sexual behaviors. Proc Natl Acad Sci USA 2006;103: 10456-10460.

9 Pfaff DW, Lewis C, Diakow C, Keiner M: Neurophysiological analysis of mating behavior as hormone-sensitive reflexes. Progr Physiol Psychol 1973;5:253-297.

10 Ågmo A, Turi AL, Ellingsen E, Kaspersen H: Preclinical models of sexual desire: conceptual and behavioral analyses. Pharmacol Biochem Behav 2004;78:379-404.

11 Ågmo A: Functional and Dysfunctional Sexual Behavior. A Synthesis of Neuroscience and Comparative Psychology. San Diego, Academic Press, 2007

12 Ågmo A: Sexual motivation. An inquiry into events determining the occurrence of sexual behavior. Behav Brain Res 1999;105:129150.

13 Pfeifle JK, Edwards DA: Midbrain lesions eliminate sexual receptivity but spare sexual motivation in female rats. Physiol Behav 1983;31:385-389.
14 Rivas FJ, Mir D: Effects of nucleus accumbens lesion on female rat sexual receptivity and proceptivity in a partner preference paradigm. Behav Brain Res 1990;41:239-249.

15 Sakuma Y: Neural substrates for sexual preference and motivation in the female and male rat. Ann NY Acad Sci 2008;1129:5560.

16 Clark AS, Kelton M, Guarraci FA, Clyons EQ: Hormonal status and test condition, but not sexual experience, modulate partner preference in female rats. Horm Behav 2004; 45:314-323.

17 Spiteri T, Ågmo A: Modèles precliniques du désir sexuel. Sexologies 2006;15:241-249.

18 Scott JW, Pfaff DW: Behavioral and electrophysiological responses of female mice to male urine odors. Physiol Behav 1970;5:407411.

19 Moncho-Bogani J, Lanuza E, Lorente MJ, Martinez-Garcia F: Attraction to male pheromones and sexual behaviour show different regulatory mechanisms in female mice. Physiol Behav 2004;81:427-434.

-20 Clark AS, Pfeifle JK, Edwards DA: Ventromedial hypothalamic damage and sexual proceptivity in female rats. Physiol Behav 1981;27:597-602. 
-21 Emery DE, Moss RL: Lesions confined to the ventromedial hypothalamus decrease the frequency of coital contacts in female rats. Horm Behav 1984;18:313-329.

-22 Hernández-González M, Guevara MA, Ågmo A: Motivational influences on the degree and direction of sexual attraction. Ann NY Acad Sci 2008;1129:61-87.

23 Romero PR, Beltramino CA, Carrer HF: Participation of the olfactory system in the control of approach behavior of the female rat to the male. Physiol Behav 1990;47:685-690.

-24 Kondo Y, Sakuma Y: The medial amygdala controls the coital access of female rats: a possible involvement of emotional responsiveness. Jap J Physiol 2005;55:345-353.

25 Canteras NS, Simerly RB, Swanson LW: Organization of projections from the medial nucleus of the amygdala: a PHAL study in the rat. J Comp Neurol 1995;360:213-245.

-26 Ågmo A: Unconditioned sexual incentive motivation in the male Norway rat (Rattus norvegicus). J Comp Psychol 2003;117:3-14.

-27 Ellingsen E, Ågmo A: Sexual-incentive motivation and paced sexual behavior in female rats after treatment with drugs modifying dopaminergic neurotransmission. Pharmacol Biochem Behav 2004;77:431-445.

$\checkmark 28$ Meerts SH, Clark AS: Stimulus animal characteristics do not modulate the expression of partner preference by female rats. Physiol Behav 2006;89:623-626.

-29 Clark AS, Kelton M, Guarraci FA, Clyons EQ: Hormonal status and test condition, but not sexual experience, modulate partner preference in female rats. Horm Behav 2004; 45:314-323.

- 30 Brown RE: Odor preference and urine-marking scales in male and female rats: effect of gonadectomy and sexual experience on response to conspecific odors. J Comp Physiol Psychol 1977;91:1190-1206.

31 Zar J: Biostatistical Analysis. Englewood Cliffs, Prentice-Hall, 1999.

32 Sorwell KG, Wesson DW, Baum MJ: Sexually dimorphic enhancement by estradiol of male urinary odor detection thresholds in mice. Behav Neurosci 2008;122:788-793.

33 Le Magnen J: Les phenomènes olfactosexuels chez le rat blanc. Arch Sci Physiol 1952;6:295-331.

- 34 Pietras RJ, Moulton DG: Hormonal influences on odor detection in rats: changes associated with estrous cycle, pseudopregnan$\mathrm{cy}$, ovariectomy, and administration of testosterone propionate. Physiol Behav 1974; 12:475-491.

- 35 Bakker J, van Ophemert J, Slob AK: Sexual differentiation of odor and partner preference in the rat. Physiol Behav 1996;60:489494.

36 Hosokawa N, Chiba A: Effects of sexual experience on conspecific odor preference and male odor-induced activation of the vomeronasal projection pathway and the nucleus accumbens in female rats. Brain Res 2007;1175: 66-75.
7 Keller M, Douhard Q, Baum MJ, Bakker J: Destruction of the main olfactory epithelium reduces female sexual behavior and olfactory investigation in female mice. Chem Senses 2006;31:315-323.

38 Carr WJ, Loeb LS, Dissinger ML: Responses of rats to sex odors. J Comp Physiol Psychol 1965;59:370-377.

39 Xiao K, Kondo Y, Sakuma Y: Sex-specific effects of gonadal steroids on conspecific odor preference in the rat. Horm Behav 2004;46: 356-361.

40 Xiao K, Kondo Y, Sakuma Y: Differential regulation of female rat olfactory preference and copulatory pacing by the lateral septum and medial preoptic area. Neuroendocrinology 2005;81:56-62.

41 Licht G, Meredith M: Convergence of main and accessory olfactory pathways onto single neurons in the hamster amygdala. Exp Brain Res 1987;69:7-18.

42 Shipley MT, Ennis M, Puche AC: Olfactory system; in Paxinos G (ed): The Rat Nervous System. London, Elsevier, 2004, pp $923-$ 964.

43 Parfenova EV: Binding of ${ }^{3} \mathrm{H}$-estradiol to cytosol receptor sites in olfactory tissue of the rats. Tsitologiia 1986;28:570-573.

44 Shinoda K, Shiotani Y, Osawa Y: Necklace olfactory glomeruli form unique components of the rat primary olfactory system. J Comp Neurol 1989;284:362-373.

45 Pfaff DW: Uptake of ${ }^{3} \mathrm{H}$-estradiol by the female rat brain. An autoradiographic study. Endocrinology 1968;82:1149-1155.

- 46 Simerly RB, Chang C, Muramatsu M, Swanson LW: Distribution of androgen and estrogen receptor mRNA-containing cells in the rat brain: an in situ hybridization study. J Comp Neurol 1990;294:76-95.

47 Shugrue PJ, Lane MV, Merchenthaler I: Comparative distribution of estrogen receptor- $\alpha$ and $-\beta$ in the rat central nervous system. J Comp Neurol 1997;388:507-525.

48 Krieger MS, Conrad LCA, Pfaff DW: Autoradiographic study of the efferent connections of the ventromedial nucleus of the hypothalamus. J Comp Neurol 1979;183: 785-815.

-49 Pfeifle JK, Edwards DA: Midbrain lesions eliminate sexual receptivity but spare sexual motivation in female rats. Physiol Behav 1983;31:385-389.

50 Pfaff DW, Sakuma Y: Deficit in the lordosis reflex of female rats caused by lesions in the ventromedial nucleus of the hypothalamus. J Physiol 1979;288:203-210.

51 Mathews D, Edwards DA: Involvement of the ventromedial and anterior hypothalamic nuclei in the hormonal induction of receptivity in the female rat. Physiol Behav 1977; 19:319-326.
52 Richmond G, Clemens LG: Ventromedial hypothalamic lesions and cholinergic control of female sexual behavior. Physiol Behav 1988;42:179-182.

53 Howard SB, Etgen AM, Barfield RJ: Antagonism of central estrogen action by intracerebral implants of tamoxifen. Horm Behav 1984;18:256-266.

54 Meisel RL, McEwen BS, Pfaff DW: Antagonism of sexual behavior in female rats by ventromedial hypothalamic implants of antiestrogen. Neuroendocrinology 1987;45: 201-207.

55 Pleim ET, Brown TJ, MacLusky NJ, Etgen AM, Barfield RJ: Dilute estradiol implants and progestin receptor induction in the ventromedial nucleus of the hypothalamus: Correlation with receptive behavior in female rats. Endocrinology 1989;124:18071812.

56 Barfield RJ, Chen JJ: Activation of estrous behavior in ovariectomized rats by intracerebral implants of estradiol benzoate. Endocrinology 1977;101:1716-1725.

57 Canteras NS, Simerly RB, Swanson LW: Organization of projections from the ventromedial nucleus of the hypothalamus: a Phaseolus vulgaris leukoagglutinin study in the rat. J Comp Neurol 1994;348:41-79.

58 Hennessey AC, Camak L, Gordon F, Edwards DA: Connections between the pontine central gray and the ventromedial hypothalamus are essential for lordosis in female rats. Behav Neurosci 1990;104:477-488.

-59 Rothfeld JM, Harlan RE, Shivers BD, Pfaff DW: Reversible disruption of lordosis via midbrain infusions of procaine and tetrodotoxin. Pharmacol Biochem Behav 1986;25: 857-863.

60 Barfield RJ, Chen JJ: Activation of estrous behavior in ovariectomized rats by intracerebral implants of estradiol benzoate. Endocrinology 1977;101:1716-1725.

-61 Sakuma Y, Pfaff DW: Excitability of female rat central gray cells with medullary projections: Changes produced by hypothalamic stimulation and estrogen treatment. J Neurophysiol 1980;44:1012-1022.

62 Rizvi TA, Ennis M, Shipley MT: Reciprocal connections between the medial preoptic area and the midbrain periaqueductal gray in rat: A WGA-HRP and Pha-l study. J Comp Neurol 1992;315:1-15.

63 Edwards DA, Warner P: Olfactory bulb removal facilitates the hormonal induction of sexual receptivity in the female rat. Horm Behav 1972;3:321-332.

64 Al Satli M, Aron C: Influence of olfactory bulb removal on sexual receptivity in the rat. Psychoneuroendocrinology 1977;2:399-407.

65 McGinnis MY, Nance DM, Gorski AR: Olfactory, septal and amygdala lesions alone or in combination: effects on lordosis behavior and emotionality. Physiol Behav 1978;20: 435-440. 
66 Williams GW, McGinnis MY, Lumia AR: The effects of olfactory bulbectomy and chronic psychosocial stress on serum glucocorticoids and sexual behavior in female rats. Physiol Behav 1992;52:755-760.

67 Williams GW, Goldman J, McGinnis MY, Possidente B, Lumia AR: Effects of ovarian hormones on sexual receptivity, proceptivity, and motivation in olfactory bulbectomized female rats. Physiol Behav 1991;50: 751-755.

68 Polston EK, Erskine MS: Excitotoxic lesions of the medial amygdala differentially disrupt prolactin secretory responses in cycling and mated female rats. J Neuroendocrinol 2001; 13:13-21.
69 Mascó DH, Carrer HF: Sexual receptivity in female rats after lesion or stimulation of different amygdaloid nuclei. Physiol Behav 1980;24:1073-1080.

70 Guarraci FA, Megroz AB, Clark AS: Paced mating behavior in the female rat following lesions of three regions responsive to vaginocervical stimulation. Brain Res 2004;999: 40-52.

71 Jacob DA, Temple JL, Patisaul HB, Young LJ, Rissman EF: Coumestrol antagonizes neuroendocrine actions of estrogen via the estrogen receptor $\alpha$. Proc Soc Exp Biol Med 2001;226:301-306

72 Beach FA: Importance of progesterone to induction of sexual receptivity in spayed female rats. Proc Soc Exp Biol Med 1942;51: 369-371.

73 Brandling-Bennett EM, Blasberg ME, Becker JB: Paced mating behavior in female rats in response to different hormone priming regimens. Horm Behav 1999;35:144154
74 Moffat CA, Rissman EF, Shupnik MA, Blaustein JD: Induction of progestin receptors by estradiol in the forebrain of estrogen receptor- $\alpha$ gene-disrupted mice. J Neurosci 1998;18:9556-9563.

75 Shughrue PJ, Askew GR, Dellovade TL, Merchenthaler I: Estrogen-binding sites and their functional capacity in estrogen receptor double knockout mouse brain. Endocrinology 2002;143:1643-1650.

76 Kudwa AE, Rissman EF: Double oestrogen receptor $\alpha$ and $\beta$ knockout mice reveal differences in neural oestrogen-mediated progestin receptor induction and female sexual behaviour. J Neuroendocrinol 2003;15:978983. 